University of Nebraska - Lincoln

DigitalCommons@University of Nebraska - Lincoln

PULSATILE LUTEINIZING HORMONE SECRETION IN THE CASTRATE MALE BOVINE: EFFECTS OF TESTOSTERONE OR ESTRADIOL REPLACEMENT THERAPY

\author{
B. D. Schanbacher \\ USDA-ARS \\ M. J. D'Occhio \\ University of Nebraska-Lincoln \\ T. W. Gettys \\ USDA-ARS
}

Follow this and additional works at: https://digitalcommons.unl.edu/usdaarsfacpub

Part of the Agricultural Science Commons

Schanbacher, B. D.; D'Occhio, M. J.; and Gettys, T. W., "PULSATILE LUTEINIZING HORMONE SECRETION IN THE CASTRATE MALE BOVINE: EFFECTS OF TESTOSTERONE OR ESTRADIOL REPLACEMENT THERAPY" (1983). Publications from USDA-ARS / UNL Faculty. 766.

https://digitalcommons.unl.edu/usdaarsfacpub/766

This Article is brought to you for free and open access by the U.S. Department of Agriculture: Agricultural Research Service, Lincoln, Nebraska at DigitalCommons@University of Nebraska - Lincoln. It has been accepted for inclusion in Publications from USDA-ARS / UNL Faculty by an authorized administrator of DigitalCommons@University of Nebraska - Lincoln. 


\title{
PULSATILE LUTEINIZING HORMONE SECRETION IN THE CASTRATE MALE BOVINE: EFFECTS OF TESTOSTERONE OR ESTRADIOL REPLACEMENT THERAPY ${ }^{1}$
}

\author{
B. D. Schanbacher, M. J. D'Occhio ${ }^{2}$ and T. W. Gettys ${ }^{3}$ \\ US Department of Agriculture ${ }^{4,5}$, Clay Center, NE 68933
}

\section{Summary}

Luteinizing hormone (LH) secretory profiles have been determined for the male bovine following castration and steroid replacement therapy. Serum LH concentrations increased approximately threefold during the first week following castration and thereafter remained elevated $(6.6 \pm .7 \mathrm{ng} / \mathrm{ml})$. Castrates not receiving steroid replacement showed a rhythmic pattern of LH release that was of high frequency (mean pulse interval; $85 \pm 5 \mathrm{~min}$ ) and high amplitude (mean peak concentration, $11.2 \pm 1.4 \mathrm{ng} / \mathrm{ml}$ ). Chronic administration of estradiol- $17 \beta$ via subdermal Silastic implants reduced mean serum LH concentrations $(2.1 \pm .3 \mathrm{ng} / \mathrm{ml})$ and blocked the pulsatile pattern of $\mathrm{LH}$ release in all steers. Similar administration of testosterone suppressed mean serum $\mathrm{LH}$ and blocked pulsatile LH release in two of four animals. The number - of implants used in this study provided physiological concentrations of estradiol $(9.8 \pm$

\footnotetext{
${ }^{1}$ Published as Paper No. 6770, Journal Series, Nebraska Agr. Exp. Sta. The authors acknowledge the technical assistance of Jim Green, Cindy Rainbolt, Kathy Sorenson and Kathy Leising and the cooperation of the Univ, of Nebraska and the Nebraska Agr. Exp. Sta. In addition, we gratefully acknowledge Dr. D. J. Bolt, USDA, ARS, Beltsville, MD, for LH antiserum (DJB 3-12/11), Dr. L. E. Reichert, Emory Univ., Atlanta, GA, for purified ovine LH (LER 1065C2) and the Endocrine Study Section, National Institutes of Health, Bethesda, MD, for the bovine reference standard (NIH-LH-B10).

${ }^{2}$ Michael J. D'Occhio is a Univ. of Nebraska Research Fellow located at the Roman L. Hruska U.S. Meat Animal Research Center, Clay Center, NE.

${ }^{3}$ Tom W. Gettys is a Clemson Univ. Graduate Fellow located at the Roman L. Hruska U.S. Meat Animal Research Center, Clay Center, NE.

${ }^{4}$ Roman L. Hruska U.S. Meat Animal Research Center, ARS.

${ }^{5}$ Mention of trade names or companies does not constitute an implied warranty or endorsement by the authors or USDA.
}

$1.5 \mathrm{pg} / \mathrm{ml})$ and testosterone $(4.1 \pm .2 \mathrm{ng} / \mathrm{ml})$ in systemic blood for the two respective treatment groups. Differences in the LH secretory profiles among testosterone-implanted steers may have been related, in part, to differences in the amounts of steroid not bound to serum proteins. These findings demonstrate that estradiol is a particularly potent inhibitor of pulsatile $\mathrm{LH}$ secretion in the male bovine and suggest that gonadal steroid feedback on LH secretion may, in part, be imposed at the level of the hypothalamus. The mechanism for pulsatile $\mathrm{LH}$ release is discussed relative to a centrally-located luteinizing hormone releasing hormone pulse generator.

(Key Words: Luteinizing Hormone Secretion, Steers, Negative Feedback, Testosterone, Estradiol.)

\section{Introduction}

Castration results in an increase in the frequency of pituitary luteinizing hormone (LH) discharges with a concomitant rise in circulating LH concentrations in rats (Gay and Sheth, 1972), dogs (Vincent et al., 1979), rams (Riggs and Malven, 1974), rhesus monkeys (Plant et al., 1978) and men (Santen and Bardin, 1973). The changes in the dynamics of LH secretion after castration are attributed to removal of negative feedback signals normally imposed by gonadal steroids (Schanbacher, 1980 a). Testosterone appears to be the steroid primarily responsible for regulating $\mathrm{LH}$ secretion in the ram (D'Occhio et al., 1982b); however, long-term castrated rams (Edgerton and Baile, 1977), bulls (D'Occhio et al., 1982a) and rhesus monkeys (Winters et al., 1981) show an insensitivity to androgen feedback. Estradiol, on the other hand, is effective in suppressing $\mathrm{LH}$ in long-term castrated rams (Schanbacher and Ford, 1977) and bulls (D'Occhio et al., 1982a). The ability of testosterone to be converted to 
estradiol in the male brain (Naftolin et al., 1975); plus the potency with which this estrogen suppresses LH in castrates, suggest that estradiol may play an important role in regulating $\mathbf{L H}$ secretion in the intact male.

The absence of information concerning the effects of castration and simultaneous hormone replacement therapy on the patterns of $\mathrm{LH}$ secretion in the acutely castrated male bovine prompted the present investigation. The objectives were 1) to monitor changes in the pattern of LH secretion in the male bovine following castration and 2) to determine the consequences of testosterone or estradiol replacement therapy on the secretory patterns of LH.

\section{Materials and Methods}

Twelve Hereford crossbred bulls were castrated at 9 mo of age and randomly assigned to one of three treatments $(n=4)$. Animals in group I were sham-implanted with empty polydimethylsiloxane (PDS) capsules at the time of castration and served as controls. Group II calves were each implanted with sixteen $30-\mathrm{cm}$ testosterone-filled PDS capsules and group III calves each received one $27-\mathrm{cm}$ estradiol-filled PDS capsule. The PDS capsules were prepared from Silastic medical grade tubing ${ }^{6}(3.35 \mathrm{~mm}$ id $x$ $4.65 \mathrm{~mm} \mathrm{od}$ ) and filled with crystalline testosterone or estradiol-17 $\beta^{7}$ as described elsewhere (Schanbacher, 1980b). The capsules were placed sc over the ribs as described previously for cattle (Schanbacher, 1981). No complications were observed with the implants.

Blood was collected by jugular venipuncture at the time of castration (between 0800 and $0900 \mathrm{~h}$ on $\mathrm{d} 0$ ) and at frequent intervals through d 18. Four weeks after castration and implantation, all 12 calves were adapted to individual stalls, equipped with a jugular cannula (Intramedic polyethylene tubing ${ }^{8}, 1.19 \mathrm{~mm}$ id $\times 1.7$ $\mathrm{mm} \mathrm{od}$ ) and bled at 10-min intervals for $6 \mathrm{~h}$, beginning at $1200 \mathrm{~h}$. Blood samples were allowed to clot overnight at $4 \mathrm{C}$ and then centrifuged at $800 \times \mathrm{g}$. The sera were stored at $-20 \mathrm{C}$.

Serum LH concentrations were determined for all samples in a single assay by the double antibody radioimmunoassay procedure described by Schanbacher (1979). Sensitivity of

\footnotetext{
${ }^{6}$ Dow Corning, Midland, MI.

${ }^{7}$ Sigma Chemical Co., St. Louis, MO.

${ }^{8}$ Clay Adams, Parsippany, NJ.
}

this assay was $.5 \mathrm{ng} \mathrm{NIH-LH-B10/ml} \mathrm{and} \mathrm{the}$ intra-assay coefficient of variation for duplicate determinations was $<10 \%$. Serum concentrations of testosterone and estradiol were determined in hourly samples taken during the 6-h intensive bleed at wk 4 . Testosterone was measured by a direct double antibody radioimmunoassay with a sensitivity of $100 \mathrm{pg} / \mathrm{ml}$ (Schanbacher and D'Occhio, 1982), whereas estradiol was measured by an extraction, charcoal precipitation assay (D'Occhio et al., $1982 \mathrm{~b}$ ). Sensitivity of the latter assay was 2 $\mathrm{pg} / \mathrm{ml}$. The intra-assay coefficient of variation was $<10 \%$ for testosterone and $<12 \%$ for estradiol. The percentage of testosterone and estradiol not bound to serum proteins was determined by the procedure of Hammond et al. (1980) with slight modification. In brief, tritium-labelled testosterone or estradiol were added together with ${ }^{14} \mathrm{C}$-glucose to duplicate serum samples. The serum was incubated at 37 $\mathrm{C}$ for $1 \mathrm{~h}$ and then transferred to glass tubing $(10 \mathrm{~mm}$ id $\times 40 \mathrm{~mm})$ fitted with a dialysis membrane (MW exclusion 6 to 8,000 ) at one end. These tubes were placed on filter paper inside screw-cap glass mini-vials and centrifuged at $3,000 \times \mathrm{g}$ for $1 \mathrm{~h}(37 \mathrm{C})$. The differential movement of steroid and glucose across the dialysis membrane was used to calculate the percentage free steroid according to the formula:

$\%$ free steroid $=$

$$
\begin{aligned}
& \frac{{ }^{3} \mathrm{H} \text {-steroid }(\mathrm{dpm})}{{ }^{14} \mathrm{C} \text {-glucose }(\mathrm{dpm})} \times \frac{{ }^{14} \mathrm{C} \text {-glucose }(\mathrm{dpm})}{{ }^{3} \mathrm{H} \text {-steroid }(\mathrm{dpm})} \times 100 . \\
& \text { Filtrate Retained serum }
\end{aligned}
$$

The mean intra-assay coefficients of variation for determining free estradiol and testosterone were $5.4(n=4)$ and $6.2 \%(n=4)$ while the interassay coefficients of variation were 7.3 (n $=3$ ) and $9.2 \%(n=3)$, respectively.

Treatment effects on circulating concentrations of $\mathbf{L H}$, testosterone and estradiol were evaluated by one-way analyses of variance while the postcastration rise in serum LH was evaluated by a split-plot analysis of variance (Steel and Torrie, 1960).

\section{Results}

The $\mathrm{LH}$ responses to castration and steroid replacement therapy are shown in figure 1 . Serum LH concentrations in the controls increased from $1.8 \pm .2 \mathrm{ng} / \mathrm{ml}$ to a plateau of 5.3 

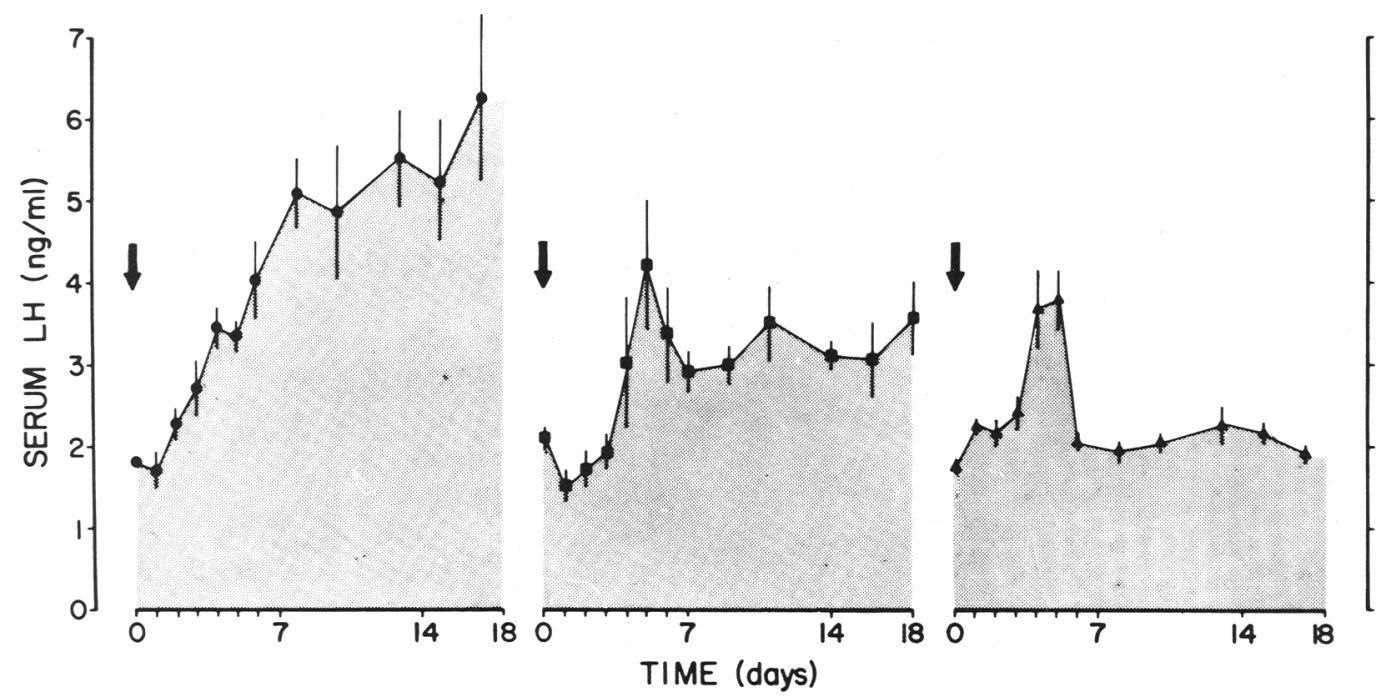

Figure 1. Mean serum LH concentrations ( \pm SE) during the first 17 or $18 \mathrm{~d}$ following castration (left panel), castration plus testosterone (middle panel) or estradiol (right panel) replacement therapy in bulls. The arrows on $\mathrm{d} O$ denote the time of castration and(or) steroid replacement therapy. Note the conspicuous peak in serum LH on $\mathrm{d} 5$ in both testosterone- and estradiol-implanted steers.

$\pm .2 \mathrm{ng} / \mathrm{ml}$ during the first week following castration. Testosterone- and estradiol-implanted calves also showed an initial rise in serum LH with peak concentrations observed on the 4th or 5 th $\mathrm{d}$ after castration and steroid treatment. Unlike the control calves, mean LH concentrations decreased thereafter to pretreatment levels in estradiol-implanted calves $(2.1 \pm .3$ $\mathrm{ng} / \mathrm{ml}$ ) and intermediate levels in testosteroneimplanted calves $(4.9 \pm 1.2 \mathrm{ng} / \mathrm{ml})$. Mean serum concentrations of $\mathrm{LH}$, testosterone and estradiol after $4 \mathrm{wk}$ of treatment are presented in table 1. The elevation in serum testosterone in testosterone-treated calves was accompanied by a small, but significant increase in serum estradiol. In contrast, serum testosterone concentrations remained low in estradiol-treated calves. The concentration and percentage of free steroid in the circulation of control and steroid-treated calves are also presented in table 1. Because of the similarity in the percentages of free steroid determined for these calves, the amounts of free testosterone and estradiol were proportional to the total amounts of these steroids in blood.

The patterns of $\mathrm{LH}$ secretion in castrates and castrates given testosterone or estradiol replacement therapy are shown in figure 2. Each of the four sham-implanted calves showed distinct pulses of LH release that occurred at intervals of $85 \pm 5 \mathrm{~min}$. These pulses were also of high amplitude, i.e., mean peak concentrations were $11.2 \pm 1.4 \mathrm{ng} / \mathrm{ml}$. Two of the testosteroneimplanted steers had $\mathrm{LH}$ profiles that were similar to those of controls. However, both the number of LH pulses and basal LH concentrations were markedly suppressed in the other two steers implanted with testosterone. Pulses of LH were not observed in estradiol-implanted steers and these animals were characterized by low, stable serum LH concentrations.

\section{Discussion}

The objectives of this study were to characterize the LH secretory pattern in the male bovine following castration and to determine the effects of chronic treatment with testosterone and estradiol. Previous investigations in this species have demonstrated an increase in mean circulating concentrations of $\mathrm{LH}$ in castrates (McCarthy and Swanson, 1976; Bass et al., 1979; Lacroix and Pelletier, 1979; D'Occhio et al., 1982a); however, the present report is the first to describe a rhythmic, pulsatile mode of $\mathrm{LH}$ secretion for steers. The pattern of $\mathrm{LH}$ secretion in steers is, therefore, very similar to that described for castrates of other species (Gay and Sheth, 1972; D'Occhio et al., 1982b). In contrast to this rhythmic pattern of secretion, intact bulls secrete LH in discrete pulses (episodes) that are of low frequency and low 


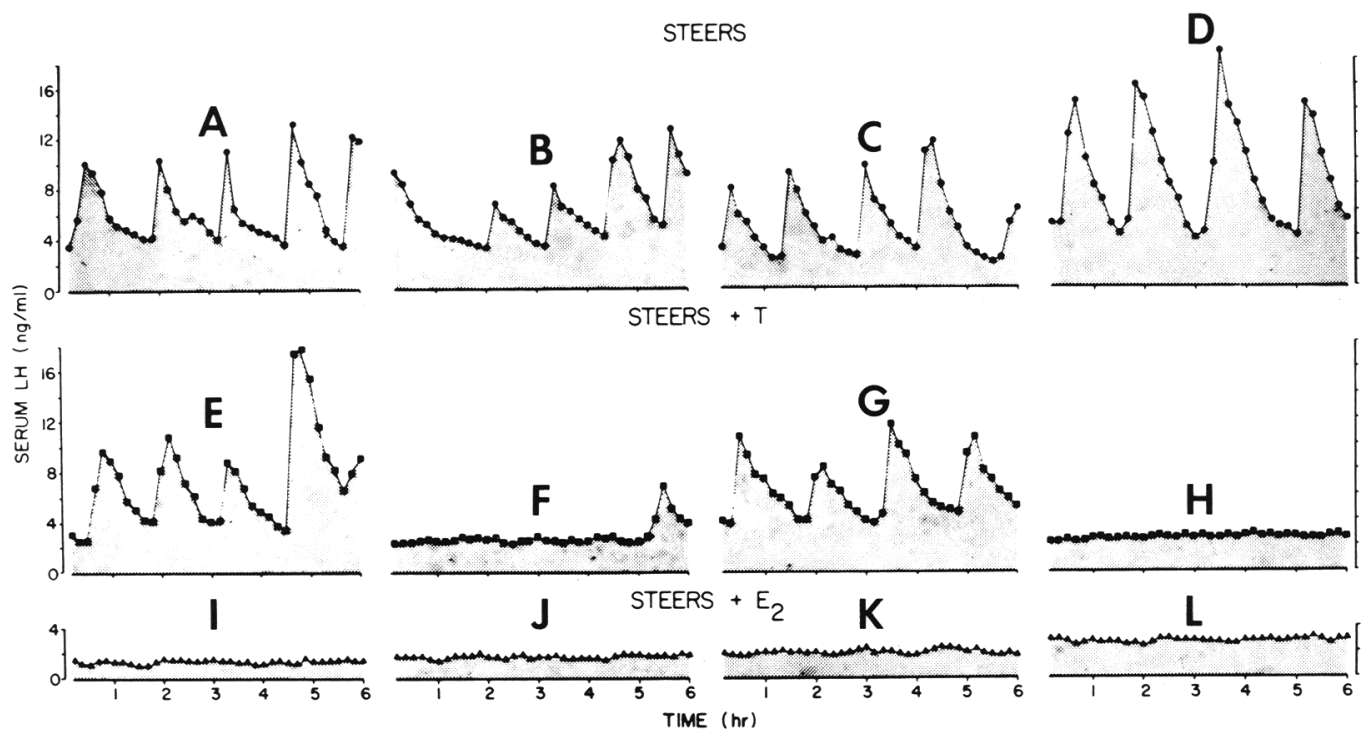

Figure 2. Serum LH profiles for each of four control steers (A through D), four testosterone-implanted steers (E through $\mathrm{H}$ ) and four estradiol-implanted steers (I through L). The profiles were obtained 4 wk after castration and steroid replacement therapy.

TABLE 1. MEAN SERUM CONCENTRATIONS OF LH, TESTOSTERONE AND ESTRADIOL AND THE AMOUNT OF FREE TESTOSTERONE AND ESTRADIOL IN THE CIRCULATION OF CONTROL STEERS (A-D) AND IN STEERS IMPLANTED 4 WK EARLIER WITH SILASTIC CAPSULES CONTAINING TESTOSTERONE (T; E-H) OR ESTRADIOL-17 $\beta\left(\mathrm{E}_{2} ; \mathrm{I}-\mathrm{L}\right.$ )

\begin{tabular}{|c|c|c|c|c|c|}
\hline \multirow[b]{2}{*}{ Treatment } & \multirow[b]{2}{*}{$\begin{array}{l}\text { Serum } \mathrm{LH} \text {, } \\
\mathrm{ng} / \mathrm{ml}\end{array}$} & \multicolumn{2}{|c|}{ Serum testosterone } & \multicolumn{2}{|c|}{ Serum estradiol } \\
\hline & & $\begin{array}{l}\text { Total, } \\
\mathrm{ng} / \mathrm{ml}\end{array}$ & $\begin{array}{l}\text { Free, } \\
\mathrm{pg} / \mathrm{ml}\end{array}$ & $\begin{array}{l}\text { Total, } \\
\mathrm{pg} / \mathrm{ml}\end{array}$ & $\begin{array}{l}\text { Free, } \\
\text { fg/ml }\end{array}$ \\
\hline \multicolumn{6}{|l|}{ Steers } \\
\hline A & 6.3 & .24 & $9.2(3.7)^{\mathrm{c}}$ & 3.9 & $142(3.6)$ \\
\hline B & 6.5 & .16 & $10.2(4.1)$ & 3.1 & $115(3.7)$ \\
\hline $\mathrm{C}$ & 5.1 & .12 & $8.8(3.5)$ & 2.2 & $76(3.4)$ \\
\hline $\mathrm{D}$ & 8.6 & .21 & $8.4(3.4)$ & 5.2 & $193(3.7)$ \\
\hline$\overline{\mathrm{X}}_{\mathrm{A}-\mathrm{D}} \pm \mathrm{SE}$ & $6.6 \pm .7^{\mathrm{d}}$ & $.18 \pm .03^{\mathrm{d}}$ & $9.1 \pm .4^{\mathrm{d}}$ & $3.6 \pm .6^{\mathrm{d}}$ & $131 \pm 24^{\mathrm{d}}$ \\
\hline \multicolumn{6}{|l|}{ Steers, $\mathrm{T}^{\mathrm{a}}$} \\
\hline $\mathrm{E}$ & 7.2 & 3.91 & $132.4(3.4)$ & 5.1 & $153(3.0)$ \\
\hline $\mathrm{F}$ & 2.9 & 4.54 & $213.0(4.7)$ & 5.4 & $188(3.5)$ \\
\hline G & 6.5 & 3.86 & $136.6(3.5)$ & 4.1 & $138(3.4)$ \\
\hline $\mathrm{H}$ & 3.0 & 4.03 & $167.2(4.2)$ & 6.4 & $201(3.1)$ \\
\hline$\overline{\mathrm{X}}_{\mathrm{E}-\mathrm{H}} \pm \mathrm{SE}$ & $4.9 \pm 1.1^{\mathrm{e}}$ & $4.09 \pm .16^{\mathrm{e}}$ & $162.3 \pm 18.6^{\mathrm{e}}$ & $5.3 \pm .5^{\mathrm{e}}$ & $176 \pm 19^{\mathrm{e}}$ \\
\hline \multicolumn{6}{|l|}{ Steers, $\mathrm{E}_{2} \mathrm{~b}$} \\
\hline I & 1.6 & .24 & $7.9(3.2)$ & 10.5 & $266(2.5)$ \\
\hline $\mathrm{J}$ & 1.8 & .16 & $10.6(4.2)$ & 5.3 & $190(3.6)$ \\
\hline $\mathrm{K}$ & 2.0 & .22 & $8.8(3.5)$ & 11.3 & $432(3.8)$ \\
\hline $\mathrm{L}$ & 2.8 & .13 & $8.0(3.2)$ & 12.0 & $406(3.4)$ \\
\hline$\overline{\mathrm{X}}_{\mathrm{I}-\mathrm{L}} \pm \mathrm{SE}$ & $2.1 \pm .3^{f}$ & $.19 \pm .03^{d}$ & $8.8 \pm .6^{\mathrm{d}}$ & $9.8 \pm 1.5^{f}$ & $298 \pm 78 \mathrm{f}$ \\
\hline
\end{tabular}

${ }^{a_{\text {Each }}}$ steer (avg wt, $370 \mathrm{~kg}$ ) received sixteen $30-\mathrm{cm}$ testosterone capsules.

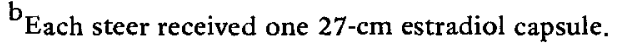

${ }^{c}$ Percentage free shown in parentheses.

$\mathrm{d}, \mathrm{e}, \mathrm{f}_{\mathrm{T}}$ Treatment means within column having different superscripts differ $(\mathrm{P}<.05)$. 
amplitude (Katongole et al., 1971; Karg et al., 1976; Schanbacher, 1979; 1981).

The pattern of LH secretion in testosteroneand estradiol-implanted steers during the first few days after castration and steroid replacement therapy was also of interest. The conspicuous LH peak observed in steroid-treated steers on $\mathrm{d} 4$ and(or) 5 was unexpected. Kesner et al. (1981) recently reported that estrogen-treated steers exhibit an LH surge comparable to that of estrogen-treated cows if exogenous luteinizing hormone releasing hormone (LHRH) is also provided. Because LHRH was not administered in the present study, it remains to be determined whether the LH peak observed in implanted steers is a consistent feature of this model.

The rhythmic pulsatile pattern of LH release observed in castrates is believed to result from a LHRH pulse generator located in the medial basal hypothalamus (Blake and Sawyer, 1974; Levine and Ramirez, 1980). In support of this theory, low-dose, pulsatile administration of exogenous LHRH is capable of reproducing the pulstatile pattern of $\mathrm{LH}$ secretion in rams (Lincoln, 1979) and bulls (Schanbacher and D'Occhio, 1982; Schanbacher et al., 1982) Furthermore, neutralization of endogenous LHRH by passive (Lincoln and Frazer, 1979) or active (Schanbacher, 1982) immunization against LHRH results in cessation of pulsatile $\mathrm{LH}$ release and failure of animals to respond to exogenous LHRH.

The increased frequency of pulsatile $\mathrm{LH}$ release in castrates suggests that the LHRH pulse generator is normally suppressed by gonadal steroids. Indeed, progesterone and estradiol suppress LH secretion in ovariectomized heifers (Beck et al., 1976) and a recent study by Rahe et al. (1980) demonstrated that frequency and amplitude modulation of pulsatile $\mathrm{LH}$ release occurs during the course of the bovine estrous cycle. The findings reported herein suggest that testosterone and estradiol can likewise modulate the pattern of $\mathrm{LH}$ secretion in the male bovine.

Inhibition of pulsatile LH secretion in only two of the four steers implanted with testosterone suggests that the dosage employed may have been near the threshold level required for LH suppression. Although serum testosterone concentrations achieved with the subdermal implants in this study were similar to those observed in intact bulls, a recent study in male sheep has indicated that relatively small incre- ments in serum testosterone are capable of causing a dramatic change in the pattern of $\mathrm{LH}$ secretion (D'Occhio et al., 1982b). Another possible explanation for the lack of LH suppression in two testosterone-implanted steers may involve differences in the amount of free steroid in the circulation available for feedback inhibition on LH. It is interesting to note that the two steers that did not respond to testosterone also had lower concentrations of free testosterone.

In seems unlikely that direct feedback effects of testosterone are required for $\mathrm{LH}$ suppression because estradiol-implanted steers, which had no appreciable testosterone, were characterized by low serum LH concentrations. Although this does not preclude the possibility of a direct involvement of testosterone in LH suppression, the effectiveness by which free testosterone exerts feedback on LH secretion might be related to the ability of free testosterone to be converted to estrogen. In this regard, the two testosterone-implanted steers that showed LH suppression also had the highest concentrations of both total and free serum estradiol for this group. These data, therefore, support the contention that systemic and central aromatization of testosterone is an important part of the testicular steroid feedback signal that regulates $\mathrm{LH}$ secretion (Naftolin et al., 1975).

Relatively low serum estradiol concentrations $(10 \mathrm{pg} / \mathrm{ml})$ were effective in blocking pulsatile LH release in estradiol-implanted steers. We have reported a similar effect of these estradiol implants in intact, pubertal age bulls (Schanbacher, 1981; Schanbacher et al., 1982). It was concluded in these latter studies that exogenous estradiol interferes with pulsatile $\mathrm{LH}$ release and testicular development by acting at the level of the LHRH pulse generator. A similar conclusion has been made from a study in which long-term castrated steers were infused with estradiol (D'Occhio et al., 1982a). Collectively, these findings demonstrate that estradiol is a particularly potent inhibitor of LH secretion in the male bovine and suggest that one important site for gonadal steroid feedback on LH secretion may be at the level of the hypothalamus.

\section{Literature Cited}

Bass, J. J., A. S. McNeilly and H. E. Moreton. 1979. Plasma concentrations of FSH and $\mathrm{LH}$ in entire and castrated prepubertal bull calves treated with Gn-RH. J. Reprod. Fertil. 57:219. 
Beck, T. W., V. G. Smith, B. E. Sequin and E. M. Convey. 1976. Bovine serum LH, GH and pro. lactin following chronic implantation of ovarian steroids and subsequent ovariectomy. J. Anim. Sci. 42:461.

Blake, C. A. and C. H. Sawyer. 1974. Effects of hypothalamic deafferentation on the pulsatile rhythm in plasma concentrations of luteinizing hormone in ovariectomized rats. Endocrinology 94:730.

D'Occhio, M. J., J. E. Kinder and B. D. Schanbacher. 1982a. Patterns of LH secretion in castrated bulls (steers) during intravenous infusion of androgenic and estrogenic steroids: Pituitary response to exogenous luteinizing hormone releasing hormone. Biol. Reprod. 26:249.

D'Occhio, M. J., B. D. Schanbacher and J. E. Kinder. 1982b. Relationship between serum testosterone concentration and patterns of LH secretion in male sheep. Endocrinology 110:1547.

Edgerton, L. A. and C. A. Baile. 1977. Serum LH suppression by estradiol but not by testosterone or progesterone in wethers. J. Anim. Sci. 44:78.

Gay, V. L. and N. A. Sheth. 1972. Evidence for a periodic release of $\mathrm{LH}$ in castrated male and female rats. Endocrinology 90:158.

Hammond, G. L., J. A. Nisker, L. A. Jones and P. K. Siiteri. 1980. Estimation of the percentage of free steroid in undiluted serum by centrifugal ultrafiltration-dialysis. J. Biol. Chem. 255:5023.

Karg, H., T. Giminez, M. Hartl, B. Hoffman, E. Schallenberger and D. Schams. 1976. Testosterone, luteinizing hormone ( $\mathrm{LH}$ ) and follicle stimulating hormone (FSH) in peripheral plasma of bulls: Levels from birth through puberty and short term variations. Zentralblatt fur Veterinarmedizin 23:793.

Katongole, C. B., F. Naftolin and R. V. Short. 1971. Relationship between blood levels of luteinizing hormone and testosterone in bulls, and the effects of sexual stimulation. J. Endocrinol. 50:457.

Kesner, J. S., E. M. Convey and C. R. Anderson. 1981. Evidence that estradiol induces the preovulatory LH surge in cattle by increasing pituitary sensitivity to LHRH and then increasing LHRH release. Endocrinology 108:1386.

Lacroix, A. and J. Pelletier. 1979. LH and testosterone release in developing bulls following LH-RH treatment. Effect of gonadectomy and chronic testosterone propionate pre-treatment. Acta Endocrinol. 91:719.

Levine, J. E. and V. D. Ramirez. 1980. In vivo release of luteinizing hormone-releasing hormone estimated with push-pull cannulae from the mediobasal hypothalami of ovariectomized, steroidprimed rats. Endocrinology 107:1782.

Lincoln, G. A. 1979. Use of a pulsed infusion of luteinizing hormone releasing hormone to mimic seasonally induced endocrine changes in the ram. J. Endocrinol. 83:251.

Lincoln, G. A. and H. M. Frazer. 1979. Blockade of episodic secretion of luteinizing hormone in the ram by the administration of antibodies to luteinizing hormone releasing hormone. Biol. Reprod. 21:1239.
McCarthy, M. S. and L. V. Swanson, 1976. Serum LH concentration following castration, steroid hormone and gonadotropin releasing hormone treatment in the male bovine. J. Anim. Sci, $43: 151$.

Naftolin, F., K. J. Ryan, F. J. Davies, V. V. Reddy, F. Flores, Z. Petro, M. Kuhn, R. T. White, Y. Takaoka and L. Wolin. 1975. The formation of estrogens by central neuroendocrine tissues. Rec. Prog. Horm. Res. 31:295.

Plant, T. M., D. L. Hess, J. Hotchkiss and E. Knobil. 1978. Testosterone and the control of gonadotropin secretion in the male rhesus monkey (Macaca mulatta). Endocrinology 103:535.

Rahe, C. H., R. E. Owens, J. L. Fleager, H. J. Newton and P. G. Harms. 1980. Pattern of plasma luteinizing hormone in the cyclic cow: Dependence upon the period of the cycle. Endocrinology 107:498.

Riggs, B. L. and P. V. Malven. 1974. Spontaneous patterns of $\mathrm{LH}$ release in castrate male sheep and the effects of exogenous estradiol. J. Anim. Sci. $38: 1239$.

Santen, R. J, and C. W. Bardin. 1973. Episodic luteinizing hormone secretion in man. Pulse analysis, clinical interpretation, physiologic mechanisms. J. Clin. Invest. 52:2617.

Schanbacher, B. D. 1979. Testosterone secretion in cryptorchid and intact bulls injected with gonadotropin-releasing hormone and luteinizing hormone. Endocrinology 104:360.

Schanbacher, B. D. 1980a. The feedback control of gonadotrophin secretion by testicular steroids. Proc. 9th Int. Congr. Anim. Prod. Artif. Insem., Madrid, Spain. RT-D-4, p 177.

Schanbacher, B. D. 1980b. Influence of testicular steroids on thyrotropin releasing hormone-induced prolactin release in mature rams. J. Androl. $1: 121$.

Schanbacher, B. D. 1981. Importance of the episodic nature of luteinizing hormone secretion for normal development of the bovine testis during puberty: Interference with oestradiol-17 $\beta$. J. Endocrinol. 88:393.

Schanbacher, B. D. 1982, Responses of ram lambs to active immunization against testosterone and luteinizing hormone releasing hormone. Amer. J. Physiol, 242:E201.

Schanbacher, B. D. and M. J. D'Occhio. 1982. Validation of a direct radioimmunoassay for testosterone in unextracted serum from five species: Application to study of the hypothalmic-pituitarygonadal axis in males. J. Androl, 3:45.

Schanbacher, B. D., M. J. D'Occhio and J. E. Kinder. 1982. Initiation of spermatogenesis and testicular growth in oestradiol-17 $\beta$-implanted bull calves with pulsatile infusion of luteinizing hormone-releasing hormone J. Endocrinol. 93: 183.

Schanbacher, B. D. and J. J. Ford. 1977. Gonadotropin secretion in cryptorchid and castrate rams and the acute effects of exogenous steroid treatment. Endocrinology 100:387.

Steel, R.G.D. and J. H. Torrie. 1960. Principles and Procedures of Statistics. McGraw-Hill Book Co., New York. p 242. 
Vincent, D. L., T. A. Kepic, J. C. Lathrop and R. E. Falvo. 1979. Testosterone regulation of luteinizing hormone secretion in the male dog. Int. J. Androl. 2:241.

Winters, S. J., P. Troen and T. M. Plant. 1981. Rela- tionship between testosterone binding globulin and the failure of androgens to suppress serum gonadotropin concentration in long-term castrated adult male rhesus monkeys (Macaca Mulatta). J. Steroid Biochem. 14:1223. 